\title{
Ki-67 protein predicts survival in oral squamous carcinoma cells: an immunohistochemical study
}

Verena Karla Monteiro LOPES(a) Adriana Souza de JESUS(a) Lucas Lacerda de SOUZA(a) Ligia Akiko Ninokata MIYAHARA ${ }^{(a)}$ Douglas Magno GUIMARÃES(a) Helder Antônio Rebelo PONTES(a) Flavia Sirotheau Correa PONTES(a) Pedro Luiz de CARVALHO(b)

(a) Universidade Federal do Pará - UFPA, João de Barros Barreto University Hospital, PA, Brazil.

(b) Universidade Federal do Pará - UFPA, Belém, PA, Brazil

Declaration of Interests: The authors certify that they have no commercial or associative interest that represents a conflict of interest in connection with the manuscript.

Corresponding Author:

Lucas Lacerda de Souza

E-mail: lucaslac@hotmail.com

Submitted: Feb 15, 2017

Accepted for publication: May 22, 2017

Last revision: June 02, 2017
Abstract: The aim of this study was to identify the expression of Ki-67 and MCM3 in oral squamous cell carcinoma (OSCC) as well as to address the correlation with patient survival and clinical features. Samples were collected from 51 patients with OSCC who presented for follow-up. Immunohistochemical expression of Ki-67 and MCM3 in all groups was performed. The scoring system was previous published by Tsurutani in 2005. We used Kappa index to evaluate observers agreement degree. The associations between protein expression and clinical variables were examined for statistical significance using the chi-squared test. The overall survival rates were estimated by the Kaplan-Meier method and the relationship between protein expression and survival was compared using the log-rank test $(p<0.05)$. The overall survival time for a patient with positive immunostaining for Ki-67 is shorter than for a patient with negative immunostaining, (log-rank test, $\mathrm{p}=0.00882$ ). Patients with tumor size T3 and T4 showed a statistically significant relationship with Ki-67 immunoexpression (log-rank test, $p=0.0174)$. The relationship between Ki-67 expression and the relation between age, gender, smoking, tumor site, lymph node metastasis and disease stage was not significant. The examiners agreement degree by Kappa presented $\mathrm{p}$ value $<0.05$. There was not a significant correlation when we evaluated $\mathrm{MCM} 3$ expression regarding clinical characteristics and survival rate. From these results, the present study suggests that positive Ki-67 expression found in OSCC patients may contribute to predict the survival in OSCC samples, as well as the relation between the protein and the tumor size.

Keywords: Mouth Neoplasms; Carcinoma, Squamous Cell; Mouth; Immunohistochemistry; Survival.

\section{Introduction}

Oral squamous cell carcinoma (OSCC) represents 95\% of all malignant neoplasms that occur in the oral cavity., It is an aggressive neoplasm with unpredictable biological behavior and an unfavorable prognosis. ${ }^{3}$ Actually, decisions on therapeutic modalities used in OSCC are based on clinical features, including the tumor size $(\mathrm{T})$, the involvement of lymph nodes $(\mathrm{N})$ and the presence of distant metastases (M), i.e. the TNM staging system. ${ }^{4,5}$ Although useful, these criteria do not explain why lesions diagnosed at 
an early stage present with a poor prognosis. In this regard, the identification of molecular markers may be a useful tool to identify a lesion's aggressiveness, especially at an early stage. $6,7,8$

$\mathrm{Ki}-67$ is expressed in proliferating cells, but quickly disappears when the cell enters into a resting state. This characteristic has stimulated the use of $\mathrm{Ki}-67$ to demonstrate the fraction of proliferating cells in a malignant neoplasm. ${ }^{6,79}$ Another group of proteins that has been recently investigated is the mini-chromosome maintenance proteins (MCM). These proteins are involved in the early stages of eukaryotic genome replication and are believed to serve as a normal component of the replication machinery. ${ }^{10}$ All six members of the MCM family, i.e. MCM2 to MCM7, form an important complex; its regulation is essential to DNA replication. ${ }^{11,12}$ It has been recently demonstrated that entry into the quiescent state causes rapid disappearance of Ki-67, followed by the disappearance of MCM3 expression. ${ }^{13}$ This indicates that the assessment of these proteins may be a useful tool to establish which cells are proliferating and which are resting.

The aim of this study was to evaluate the association between two proliferation markers, Ki-67 and MCM3, and their association with clinical features (age, gender, smoking, tumor site, tumor size, lymph node metastasis and disease stage) and overall survival in OSCC.

\section{Methodology}

\section{Specimens and inclusion criteria}

A total of 51 paraffin-embedded biopsy specimens of OSCC from $32(62.74 \%)$ males and 19 (37.26\%) females with a mean age of 63.89 (range 36-95) years were selected in the period between 1996 and 2014 from the Service of Oral Pathology of the João de Barros Barreto University Hospital (Pará, Brazil). Samples were selected from patients (with a diagnosis confirmed by histopathology) who had primary tumors of the oral cavity with only resection of the primary tumor and resection of the primary tumor associated the radiotherapy as treatment modality. The mean follow-up of the patients was 61.5 months (range, 36-161. A total of
28 patients with a change in staging in the period between diagnosis and surgery were excluded. The required data were obtained from patient records, summarized on standardized forms and stored in a database. The primary tumor was clinically staged according to the TNM classification defined by the 2009 International Union Against Cancer (UICC) ${ }^{5}$ and the 2010 American Joint Committee on Cancer (AJCC) $)^{14}$. The ethical committee of João de Barros Barreto University Hospital approved this work under approval number 51641/12.

\section{Immunohistochemistry}

Tissue sections ( $3 \mu \mathrm{m}$ thick) fixed in $4 \%$ formalin were dewaxed with xylene and rehydrated in an ethanol series. The slides were then immersed in 10 mM EDTA ( $\mathrm{pH}$ 8.0) for $15 \mathrm{~min}$ in a microwave oven. Peroxidase activity was blocked with $6 \%$ hydrogen peroxide and methanol in two baths (15 min each) at room temperature. After washing in Tris buffer ( $\mathrm{pH}$ 7.4), slides were incubated with the primary antibodies recognizing Ki-67 (1:150; Dako, Clone MIB-1, Carpinteria, CA, USA) and MCM3 (1:100; Dako, Clone 101, Carpinteria, CA, USA) for $18 \mathrm{~h}$ at $4^{\circ} \mathrm{C}$. The slides were subsequently exposed to the avidin-biotin complex (LSAB-Kit + HRP; Dako Cytomation) and to the chromogen 3,3'-diaminobenzidine (DAB+; Dako Cytomation).

Sections were counterstained with Mayer's hematoxylin, dehydrated in ethanol, cleared in xylene and mounted. Breast cancer tissues were used as a positive control for all antibodies. The negative control was obtained by omitting the primary specific antibody during the reaction. The sections that underwent immunohistochemical reactions were analyzed by a system to reduce possible distortions related to the heterogeneity of samples. The scoring system has been previously published ${ }^{15}$. The analysis was based on the intensity and distribution of staining. The distribution of stained cells was analyzed as follows: $0(0 \%), 1$ (1\% to $50 \%$ ) and 2 (51\% to $100 \%)$. The intensity of staining was rated as follows: 0 (no staining), 1 (mild staining), 2 (moderate staining) and 3 (strong staining). In addition, the immunostaining was considered specific when the immunoreactivity was mostly restricted to the nuclear region. Two independent pathologists blinded to the 
experimental groups evaluated the immunostained sections. In the event of a disagreement, the two pathologists conferred to achieve a consensus. A record card was used to the register of the inter-observer agreement among the variables through the Kappa test.

\section{Statistical analysis}

Data were analyzed using the Statistical Package for Social Sciences software for Windows, version 18.0 (SPSS Inc., Chicago, USA). Associations between $\mathrm{Ki}-67$ and MCM3 expression and clinical parameters (age, gender, smoking, tumor site, tumor size, lymph node metastasis and disease stage) were examined for statistical significance using the chi-squared test. Overall survival rates were estimated by the Kaplan-Meier method and compared using a log rank test. A p-value of $<0.05$ was considered significant.

\section{Results}

\section{Ki-67 and MCM3 immunostaining}

The immunohistochemistry results showed positive immunostaining for Ki-67 in 40/51 (78.43\%) samples and the absence of staining in 11/51 (21.57\%) samples. In positive samples, both peripheral and central cells of neoplastic islands were immunostained. Immunoreactivity for Ki-67 was restricted to the nucleus in all samples (Figure 1A-B). For MCM3, 44/51 (86.27\%) samples presented positive immunostaining and 7/51 (13.73\%) samples were negative for MCM3. Both peripheral and central cells of neoplastic islands were immunostained. Immunoreactivity for MCM3 was also restricted to the nucleus in all samples (Figure 1C-D). In order to compare the agreement among individual pathologists the unweighted kappa statistics was calculated which was found to be significant $(p<0.05)$.

\section{Clinical profiles of patients with OSCC}

A total of 51 samples were included in the analysis. The patients' clinical features and chi-squared test results are summarized in Table 1 for Ki-67 and Table 2 for MCM3.

The chi-squared test showed that the size of the tumor presented a statistically significant association with Ki-67 immunostaining ( $p=0.0174)$ (Figure 2A).
No significant relationship was found between Ki-67 immunostaining and age $(p=0.610)$, gender $(p=0.530)$, smoking $(p=0.945)$, primary tumor site $(p=0.163)$, lymph node metastasis $(p=0.106)$ or disease stage $(p=0.163)$.

Regarding MCM3 immunostaining, no significant results were found with the chi-squared test in relation to age $(p=0.476)$, gender $(p=0.811)$, smoking $(p=0.250)$, primary tumor site $(p=0.565)$, tumor size $(p=0.643)$, lymph node metastasis $(p=0.520)$ or disease stage $(p=0.811)$.

\section{Overall survival}

Concerning the patient's status, 27 are in follow-up and 24 are dead due to the disease. Overall survival was defined as the period between the date of diagnosis of the disease until the last follow-up or death. The Kaplan-Meier curve for Ki-67 showed that the probability of survival for a patient with OSCC after one month was $96 \%$; this probability tended to reduce over time, as shown in Figure 3A. The probability of a patient surviving after 60 months of follow-up was $26.83 \%$. For MCM3, the survival rate after one month of follow-up was $98.10 \%$; this also tended to decrease over time. The probability of a patient surviving after 60 months of follow-up was $14.32 \%$, which is shown in Figure 3B. Follow-up periods were available for all patients with OSCC. There was a statistically significant association between the survival rate and Ki-67 immunostaining ( $\mathrm{p}=0.00882$ ) (Figure 4A), while between survival rate and MCM3 immunostaining was not significant $(p=0,481)$.

\section{Discussion}

Despite the better understanding of the mechanisms responsible for cancer progression in recent years, the five-year survival rate of OSCC patients remains less than $50 \%$ throughout the world ${ }^{16,17}$. Based on this, molecular studies represent a useful tool to evaluate the role of proteins in the aggressiveness of human malignancies ${ }^{17,18}$. In this study, we explored two important proliferation markers (Ki-67 and MCM3) in OSCC samples and their relation to clinical features and survival rates in order to obtain more accurate information about the clinical importance of these proteins in OSCC. In our analysis, 
we found a statistically significant result when we evaluated Ki-67 immunostaining and overall survival, as well as an association between tumor size and Ki-67 expression. Concerning MCM3, no statistically significant results were found.

$\mathrm{Ki}-67$ is a nuclear non-histone protein expressed by cells in the G2 and M phases of the cell cycle ${ }^{19,20}$. Because of its high sensitivity and specificity in labeling cell proliferation in neoplastic tissues, it has been used to evaluate the aggressiveness of a neoplasm ${ }^{9}$. Ki-67 provides information about the total fraction of proliferating cells, which means that
Ki-67 labels the proportion cells in the tumor that have entered the cell cycle. Additionally, the expression of Ki-67 may also appear when DNA synthesis is blocked or in cells undergoing apoptosis ${ }^{21}$.

Some studies have recognized that the proliferation-associated antigen $\mathrm{Ki}-67$ is one of the best known predictors of survival in patients with several malignant diseases, such as lung cancer, breast cancer and prostate cancer ${ }^{22,23,24}$. In contrast, it has been reported that Ki-67 might not be the most suitable proliferation marker for use in colorectal cancer and cervical intraepithelial neoplasia ${ }^{25,26}$.
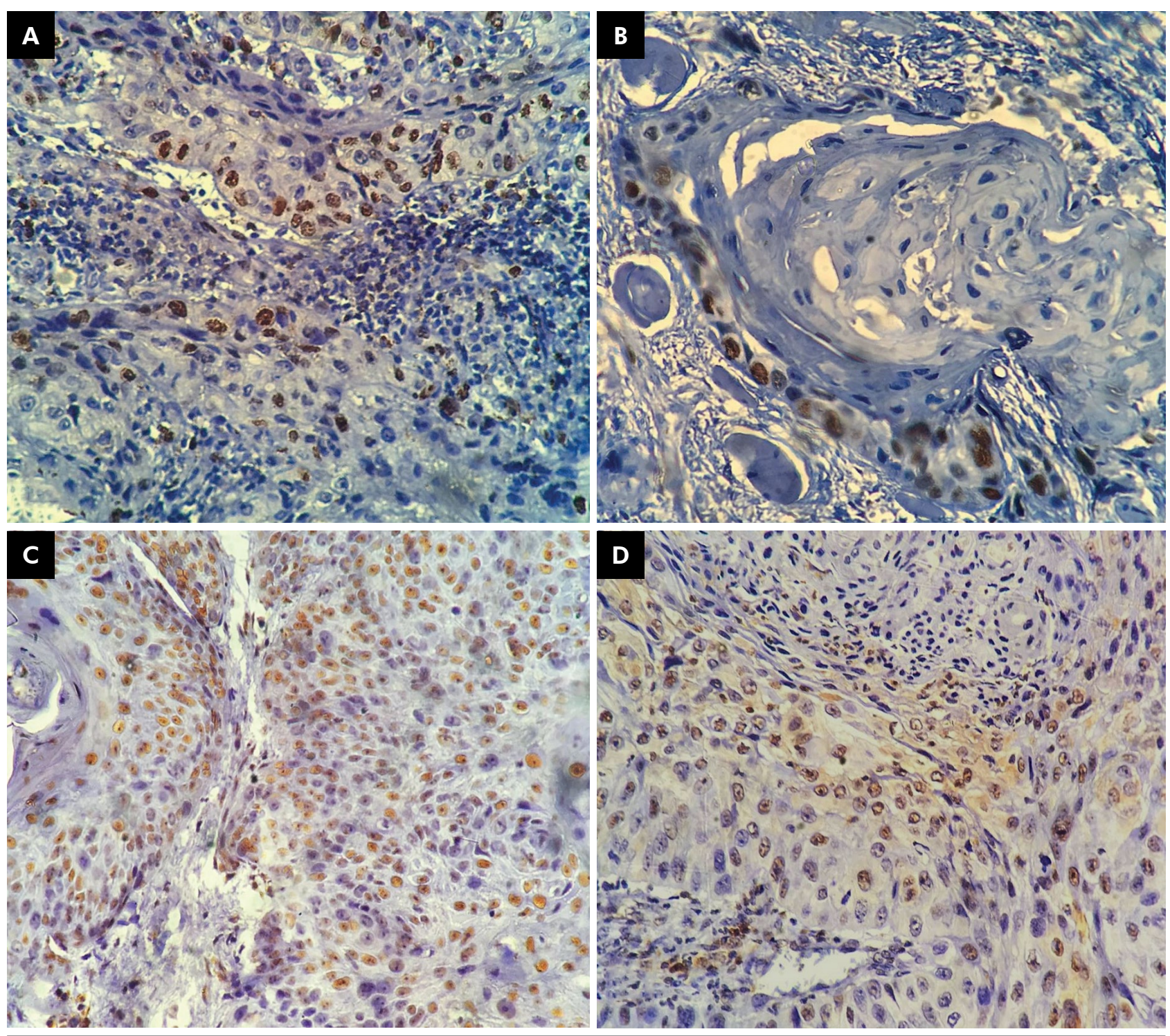

Figure 1. Immunoexpression of Ki-67 in OSCC epithelium (A). Strong immunostaining for Ki-67 in tumor strands and in tumor islands (B). Immunoexpression of MCM3 in OSCC epithelium (C). Moderate immunostaing for MCM3 in the nucleus (D). 
Table 1. Association between Ki67 immunostaining and clinicopathological characteristics.

\begin{tabular}{|c|c|c|c|c|}
\hline Clinicopathological features & Negative / (\%) & Positive / (\%) & Total / \% & p-valor \\
\hline $\mathrm{n}=51$ & $11 / 21.57 \%$ & $40 / 78.43 \%$ & $51 / 100$ & \\
\hline \multicolumn{5}{|l|}{ Age } \\
\hline$\leq 40$ years & $1 / 1.96 \%$ & $2 / 3.92 \%$ & $3 / 5.88 \%$ & \multirow{2}{*}{0.610} \\
\hline$>40$ years & $10 / 19.61 \%$ & $38 / 74.51 \%$ & $48 / 94.12 \%$ & \\
\hline \multicolumn{5}{|l|}{ Gender } \\
\hline Female & $3 / 5.88 \%$ & $15 / 29.41 \%$ & 18 / 35.29\% & \multirow{2}{*}{0.530} \\
\hline Male & $8 / 15.69 \%$ & 25 / 49.02\% & $33 / 64.71 \%$ & \\
\hline \multicolumn{5}{|l|}{ Smoking } \\
\hline No & $4 / 7.84 \%$ & $15 / 29.41 \%$ & 19 / 37.25\% & \multirow{2}{*}{0.945} \\
\hline Yes & $7 / 13.73 \%$ & 25 / 49.02\% & 32 / 62.75\% & \\
\hline \multicolumn{5}{|l|}{ Primary tumor site } \\
\hline Tongue/Floor of the mouth & $7 / 13.73 \%$ & $16 / 31.37 \%$ & $23 / 45.1 \%$ & \multirow{2}{*}{0.163} \\
\hline Other locations & $4 / 7.84 \%$ & $24 / 47.06 \%$ & $28 / 54.9 \%$ & \\
\hline \multicolumn{5}{|l|}{ T (Tumor size) } \\
\hline $\mathrm{T} 1$ or $\mathrm{T} 2$ & $7 / 13.73 \%$ & $19 / 37.25 \%$ & $26 / 50.98 \%$ & \multirow{2}{*}{0.0174} \\
\hline $\mathrm{T} 3$ or $\mathrm{T} 4$ & $4 / 7.84 \%$ & $21 / 41.18 \%$ & $25 / 49.02 \%$ & \\
\hline \multicolumn{5}{|l|}{ N (Lymph node metastasis) } \\
\hline N0 or N1 & $11 / 21.57 \%$ & 32 / 62.75\% & 43 / 84.32\% & \multirow{2}{*}{0.106} \\
\hline N2 or N3 & $0 / 0 \%$ & $8 / 15.68 \%$ & $8 / 15.68 \%$ & \\
\hline \multicolumn{5}{|l|}{ Disease stage } \\
\hline | or || & 7 / 13.73\% & $16 / 31.37 \%$ & $23 / 45.1 \%$ & \multirow{2}{*}{0.163} \\
\hline III or IV & $4 / 7.84 \%$ & 24 / $47.06 \%$ & & \\
\hline
\end{tabular}

Table 2. Association between MCM3 immunostaining and clinicopathological characteristics.

\begin{tabular}{|c|c|c|c|c|}
\hline Clinicopatholoical features & Negative / \% & Positive / \% & Total / \% & p-valor \\
\hline $\mathrm{n}=51$ & 7 / 13.73\% & 44 / $86.27 \%$ & $51 / 100 \%$ & \\
\hline \multicolumn{5}{|l|}{ Age } \\
\hline$\leq 40$ years & $0 / 0 \%$ & $3 / 5.88 \%$ & $3 / 5.88 \%$ & \multirow{2}{*}{0.476} \\
\hline$>40$ years & $7 / 13.73 \%$ & $41 / 80.39 \%$ & 48 / $94.12 \%$ & \\
\hline \multicolumn{5}{|l|}{ Gender } \\
\hline Female & $3 / 5.88 \%$ & $21 / 41.18 \%$ & $24 / 47.06 \%$ & \multirow{2}{*}{0.811} \\
\hline Male & $4 / 7.84 \%$ & $23 / 45.1 \%$ & $27 / 52.94 \%$ & \\
\hline \multicolumn{5}{|l|}{ Smoking } \\
\hline No & $1 / 1.96 \%$ & $16 / 31.37 \%$ & 17 / 33.33\% & \multirow{2}{*}{0.250} \\
\hline Yes & $6 / 11.76 \%$ & $28 / 54.91 \%$ & $34 / 66.67 \%$ & \\
\hline \multicolumn{5}{|l|}{ Primary tumor site } \\
\hline Tongue/Floor of the mouth & $4 / 7.84 \%$ & $20 / 39.22 \%$ & $24 / 47.06 \%$ & \multirow{2}{*}{0.565} \\
\hline Other locations & $3 / 5.88 \%$ & $24 / 47.06 \%$ & $27 / 52.94 \%$ & \\
\hline \multicolumn{5}{|l|}{ T (Tumor size) } \\
\hline $\mathrm{T} 1$ or $\mathrm{T} 2$ & $3 / 5.88 \%$ & $23 / 45.1 \%$ & $26 / 50.98 \%$ & \multirow{2}{*}{0.643} \\
\hline $\mathrm{T} 3$ or $\mathrm{T} 4$ & $4 / 7.84 \%$ & $21 / 41.18 \%$ & $25 / 49.02 \%$ & \\
\hline \multicolumn{5}{|l|}{ N (lymph node metastasis) } \\
\hline $\mathrm{N} 0$ or $\mathrm{N} 1$ & 5 / 9.8\% & $36 / 70.59 \%$ & $41 / 80.39 \%$ & \multirow{2}{*}{0.520} \\
\hline N2 or N3 & $2 / 3.92 \%$ & $8 / 15.69 \%$ & $10 / 19.61 \%$ & \\
\hline \multicolumn{5}{|l|}{ Disease stage } \\
\hline | or II & $3 / 5.88 \%$ & $21 / 41.18 \%$ & $24 / 47.06 \%$ & \multirow{2}{*}{0.811} \\
\hline III or IV & $4 / 7.84 \%$ & $23 / 45.1 \%$ & 27 / 52.94\% & \\
\hline
\end{tabular}




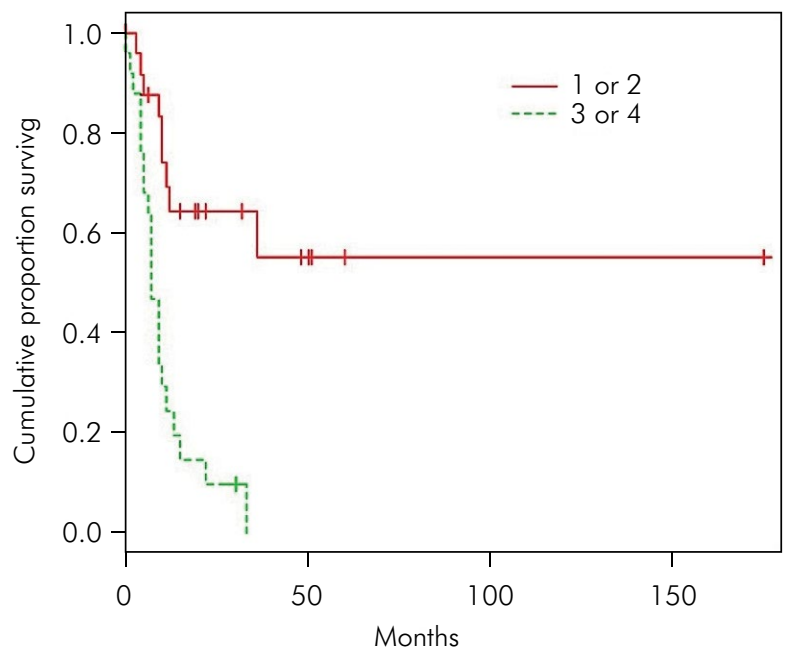

Figure 2. The Kaplan-Meier curve shows that tumor sizes $\mathrm{T} 3$ and T4 had a lower survival rate than that of $\mathrm{T} 1$ and $\mathrm{T} 2$ tumors $(p=0.0174)$.

In OSCC, studies on the value of Ki-67 expression have shown conflicting results about the relationship between Ki-67 expression and survival. In the present study, the overall survival of patients with positive Ki-67 expression was lower than that in patients with negative immunoreactivity, with a five-fold higher risk of death associated with Ki-67 expression. On the other hand, Stoll et al. ${ }^{27}$ studied 107 patients with OSCC or oropharyngeal carcinoma and found that the Ki-67 index was not able to predict survival; similar results were found by Gonzales-Moles et $\mathrm{al}^{21}$, in their evaluation of 79 OSCC samples. These conflicting results may be associated with the type of tumor or the method of immunohistochemical evaluation (quantitative, qualitative or both). Moreover, the heterogeneity of the samples may be associated with population habits, which may interfere in the behavior of the lesion.

Analyses using the TNM system have been used to evaluate the severity of disease ${ }^{4,5}$. In the current study, the samples were divided in groups 1 (T1 and T2) and 2 (T3 and T4). Regarding Ki-67 expression and tumor size, a statistically significant difference was found ( $p=0.0174$ ) as samples from group 2 presented a higher number of positive Ki-67 samples than in group 1 . It was also found that tumors in group 2 were associated with less overall survival than tumors in group $1(p=0.000029)$. These results provide evidence that the proliferative index using Ki-67 in larger
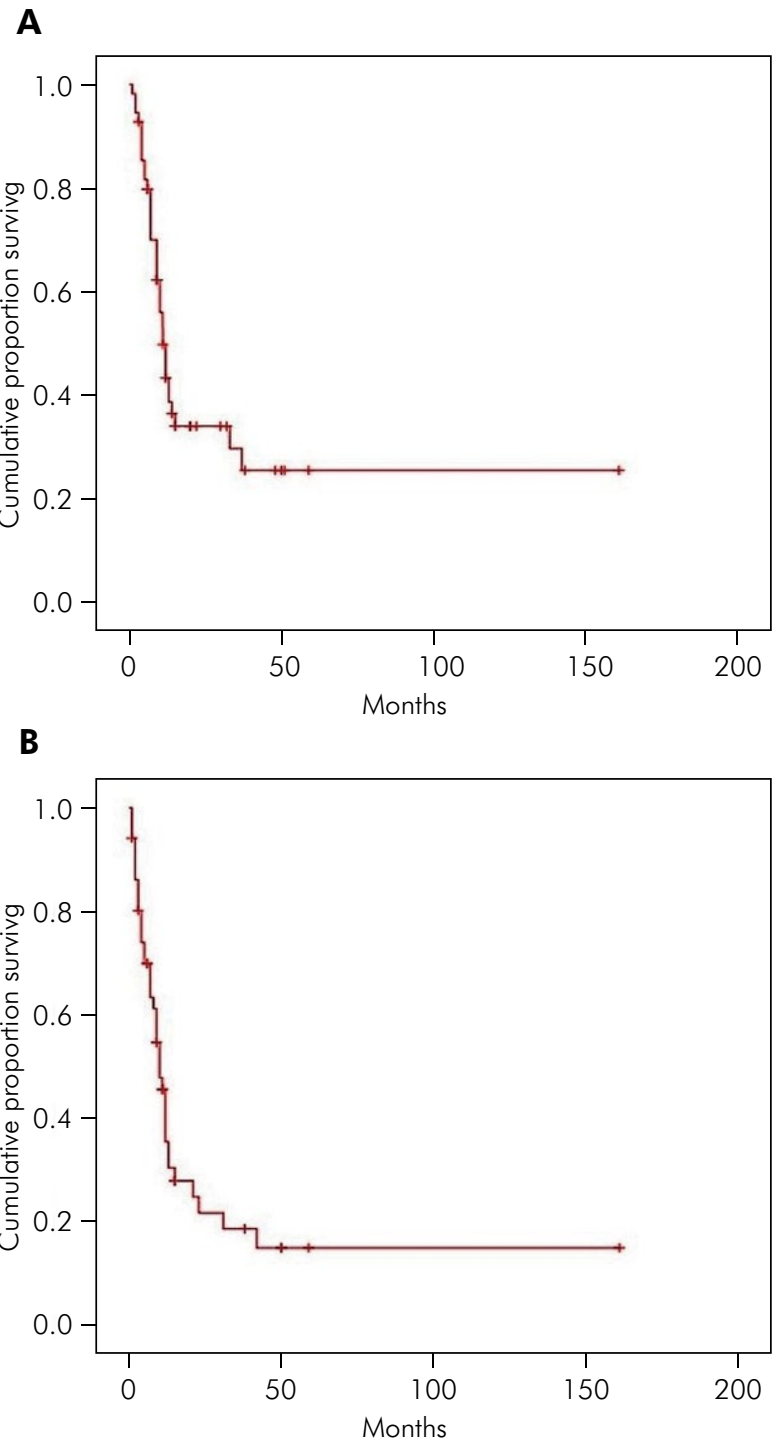

Figure 3. Kaplan-Meier curve showing the Ki-67 analysis (A). Kaplan-Meier curve showing the MCM3 results (B).

tumors interfere in the survival rates. Accordingly, Diniz and colleagues ${ }^{18}$, in a molecular study using OSCC samples, showed that larger tumors present more intense transcriptional activity of some cell cycle-related genes than smaller tumors.

No significant association between Ki-67 expression and lymph node metastasis was found in our analysis. Da Silva et al. ${ }^{28}$ studied markers in oral squamous cell carcinoma and found a significant positive association between patients with lymph node metastasis and $\mathrm{Ki}-67$ expression $(\mathrm{p}=0.021)$. These conflicting results may be due to the small number of cases with lymph 


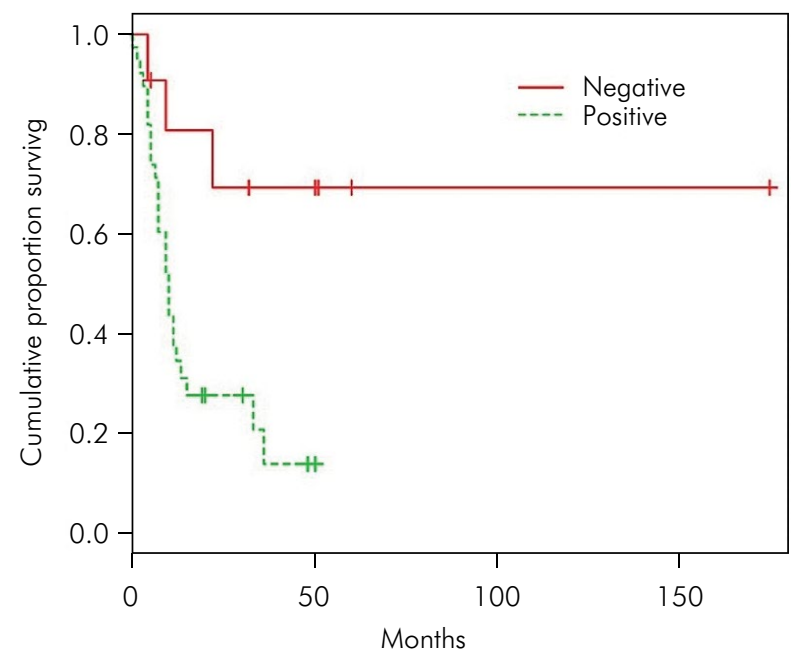

Figure 4. Kaplan-Meier curve showing the differences between Ki-67 positive and negative expression ( $p=0.00882)$.

node metastases in our study. Furthermore, our search did not discover any important data when the relationship between $\mathrm{Ki}-67$ and disease stage was analyzed.

MCM proteins are a novel class of markers used to evaluate the cell proliferation index. The MCM family has an elemental action in DNA replication, and its deregulation may be used as a prognostic indicator ${ }^{29}$. MCM proteins have been suggested to be more sensitive than Ki-67 in indicating epithelial proliferation ${ }^{30}$. MCM3 encodes for a nuclear protein of 808 amino acids; its expression is regulated in proliferating cells ${ }^{31}$. Recently, our research group has shown that MCM3 represents a useful proliferation biomarker to evaluate the progression of dysplastic lesions ${ }^{8}$.

Previous studies have reported that some MCM family proteins may be associated with overall survival in various cancers such as gliomas, malignant melanoma, anaplastic astrocytoma and medulloblastoma ${ }^{29,32,33,34}$. Conversely, Ahn et al. ${ }^{35}$ did not find any relationship between the expression of MCM family proteins and overall survival in cases of squamous cell carcinoma of the esophagus. Recently, in OSCC samples, greater immunostaining for MCM3 was observed in comparison with Ki-6736.

Our current study showed no significant results regarding prognosis and MCM3 expression. Tamura and collaborators ${ }^{37}$ evaluated 113 cases of OSCC found that high MCM7 labeling indices were significantly associated with poorer survival. Furthermore, Szelachowska et al. ${ }^{38}$, in a study using 97 OSCC samples, found a significant correlation with worse disease-specific survival in the group of patients with MCM2 protein expression, suggesting that the expression of MCM2 protein may be used as a prognostic factor. The differences between our study and these positive prognostic studies may be related to the number of analyzed samples and the heterogeneity of the samples.

Regarding the TNM system and the relationship with MCM3, no significant results were found in our study. Yu and collaborators ${ }^{39}$ studied the association between MCM3 and tumor size in OSCC samples, and reported that MCM5 protein is not only considered a proliferating cell marker, but can also stimulate cancer cell growth. Concerning lymph node metastasis, Feng et al. ${ }^{40}$ reported that MCM7 expression is correlated with metastasis to the lymph nodes and clinical TNM staging in patients with oral cancer. These results, compared to our findings, may be related to the different behavior of MCM family proteins, since we assessed MCM3 in OSCC samples.

In conclusion, studies to investigate cellular proliferation in OSCC must be expanded, since a better understanding of protein expression and the relationship between biomarkers and the clinical aspects of these patients may be useful to predict survival rates. Our findings suggest that Ki-67 represents a survival predictor protein in OSCC. Nevertheless, further studies are necessary to elucidate the behavior of MCM family proteins in OSCC samples.

\section{Acknowledgments}

This work was supported by the Brazilian Agency Fundação Amazônica Paraense de Amparo à Pesquisa (FAPESPA) and a fellowship from Conselho Nacional de Desenvolvimento Científico e Tecnológico (CNPq), Brazil.

\section{Conflict of interest}

The authors declare that they have no conflicts of interest. 


\section{References}

1. Chin D, Boyle GM, Williams RM, Ferguson K, Pandeya N, Pedley $\mathrm{J}$ et al. Novel markers for poor prognosis in head and neck cancer. Int J Cancer. 2005;113(5):789-97. https://doi.org/10.1002/iic.20608

2. Lo WL, Kao SY, Chi LY, Wong YK, Chang RC. Outcomes of oral squamous cell carcinoma in Taiwan after surgical therapy: factors affecting survival. J Oral Maxillofac Surg. 2003;61 (7):751-8. https://doi.org/10.1016/S0278-2391(03)00149-6

3. Rivera C, Venegas B. Histological and a molecular aspects of oral squamous cell carcinoma (Review). Oncol Lett. 2013;8(1):7-11. https://doi.org/10.3892/ol.2014.2103

4. Denoix PF. Tumor, node and metastasis (TNM). Bull Inst Nat Hyg (Paris). 1944;1:1-69.

5. Sobin $\mathrm{LH}$, Wittekind $\mathrm{CH}$. TNM classification of malignant tumors. 7th ed. New York: Wiley-Blackwell; 2009.

6. Vora HH, Shah NG, Patel DD, Trivedi TI, Chikhlikar PR. Prognostic significance of biomarkers in squamous cell carcinoma of the tongue: multivariate analysis. J Surg Oncol. 2003;82(1):34-50. https://doi.org/10.1002/jso.10183

7. Lameira AG, Pontes FS, Guimarães DM, Alves AC, Jesus AS, Pontes $\mathrm{HA}$ et al. $\mathrm{p}$-Akt and its relationship with clinicopathological features and survival in oral squamous cell carcinoma: an immunohistochemical study. J Oral Pathol Med. 2015;44(7):532-7. https://doi.org/10.1111/jop.12268

8. Lameira AG, Pontes FS, Guimarães DM, Alves AC, Jesus AS, Pontes HA et al. MCM3 could be a better marker than Ki-67 for evaluation of dysplastic oral lesions: an immunohistochemical study. J Oral Pathol Med. 2014;43(6):427-34. https://doi.org/10.1111/jop.12153

9. Pontes HA, Pontes FS, Silva BS, Cury SE, Fonseca FP, Salim RA et al. Immunoexpression of Ki67, proliferative cell nuclear antigen, and $\mathrm{Bcl}-2$ proteins in a case of ameloblastic fibrosarcoma. Ann Diagn Pathol. 2010;14(6):447-52. https://doi.org/10.1016/j.anndiagpath.2009.10.007

10. Han X, Mayca Pozo F, Wisotsky JN, Wang B, Jacobberger JW, Zhang Y. Phosphorylation of minichromosome maintenance 3 (MCM3) by checkpoint kinase 1 (Chk1) negatively regulates DNA replication and checkpoint activation. J Biol Chem. 2015;290(19):12370-8. https://doi.org/10.1074/jbc.M114.621532

11. Szelachowska J, Dziegiel P, Jelen-Krzeszewska J, Jelen M, Tarkowski R, Spytkowska B et al. Correlation of metallothionein expression with clinical progression of cancer in the oral cavity. Anticancer Res. 2009;29(2):589-96.

12. Tamura T, Shomori K, Haruki T, Nosaka K, Hamamoto Y, Shiomi et al. Minichromosome maintenance- 7 and geminin are reliable prognostic markers in patients with oral squamous cell carcinoma: immunohistochemical study. J Oral Pathol Med. 2010;39(4):328-34. https://doi.org/10.1111/i.1600-0714.2009.00861.x
13. Endl E, Kausch I, Baack M, Knippers R, Gerdes J, Scholzen T. The expression of $\mathrm{KI}-67, \mathrm{MCM} 3$, and p27 defines distinct subsets of proliferating, resting, and differentiated cells. J Pathol. 2001;195(4):457-52.

14. Edge SB, Compton CC. The American Joint Committee on Cancer:the 7th edition of the AJCC cancer staging manual and the future of TNM. Ann Surg Oncol. 2010;17(6):1471-4. https://doi.org/10.1245/s10434-010-0985-4

15. Tsurutani J, Castillo SS, Brognard J, Granville CA, Zhang C, Gills JJ et al. Tobacco components stimulate Akt-dependent proliferation and NFkappaB-dependent survival in lung cancer cells. Carcinogenesis. 2005;26(7):1182-95. https://doi.org/10.1093/carcin/bgi072

16. Pontes FS, Carneiro Junior JT, Fonseca FP, Silva TS, Pontes HA, Pinto DS Jr. Squamous cell carcinoma of the tongue and floor of the mouth:analysis of survival rate and independent prognostic factors in the Amazon region. J Craniofac Surg. 2011;22(3):925-30. https://doi.org/10.1097/SCS.0b013e31820felcb

17. Li Y, Li B, Xu B, Han B, Xia H, Chen QM et al. Expression of p53, p21(CIP1/WAF1) and elF4E in the adjacent tissues of oral squamous cell carcinoma: establishing the molecular boundary and a cancer progression model. Int J Oral Sci 2015;7(3):161-8. https://doi.org/10.1038/ijos.2015.5

18. Diniz MG, Silva JF, de Souza FT, Pereira NB, Gomes CC, Gomez RS. Association between cell cycle gene transcription and tumor size in oral squamous cell carcinoma. Tumour Biol. 2015;36(12):9717-22. https://doi.org/10.1007/s13277-015-3735-1

19. Kumar P, Kane S, Rathod GP. Coexpression of p53 and $\mathrm{Ki}-67$ and lack of c-erbB2 expression ion oral leukoplakias in India. Braz Oral Res. 2012;26(3):228-34. https://doi.org/10.1590/S1806-83242012000300008

20. Bôas DS, Takiya CM, Coelho-Sampaio TL, Monção-Ribeiro LC, Ramos EA, Cabral MG et al. Immunohistochemical detection of $\mathrm{Ki}-67$ is not associated with tumor-infiltrating macrophages and cyclooxygenase-2 in oral squamous cell carcinoma. J Oral Pathol Med. 2010;39(7):565-70. https://doi.org/10.1111/j.1600-0714.2010.00883.x

21. Gonzalez-Moles MA, Ruiz-Avila I, Gil-Montoya JA, Esteban F, Bravo M. Analysis of Ki-67 expression in oral squamous cell carcinoma: why $\mathrm{Ki}-67$ is not a prognostic indicator. Oral Oncol. 2010;46(7):525-30. https://doi.org/10.1016/i.oraloncology.2010.03.020

22. Martin B, Paesmans M, Mascaux C, Berghmans T, Lothaire P, Meert AP et al. Ki-67 expression and patients survival in lung cancer: systematic review of the literature with meta-analysis. Br J Cancer. 2004;91(12):2018-25. https://doi.org/10.1038/sj.bjc.6602233

23. Yang XQ, Wang FB, Chen C, Peng CW, Zhang JF, Li Y. High $\mathrm{Ki}-67$ expression is a poor prognostic indicator of 5 -year recurrence free survival in patients with invasive breast cancer. Asian Pac J Cancer Prev. 2011;12(11):3101-5. 
Lopes VKM, Jesus AS, Souza LL, MIyahara LAN, Guimarães DM, Pontes HAR et al.

24. Aaltomaa S, Käriä V, Lipponen $P$, Isotalo T, Kankkunen JP, Talja M et al. Expression of Ki-67, cyclin D1 and apoptosis markers correlated with survival in prostate cancer patients treated by radical prostatectomy. Anticancer Res. 2006;26(6C):4873-8.

25. Martins SF, Amorim R, Mota SC, Costa L, Pardal F, Rodrigues $\mathrm{M}$ et al. $\mathrm{Ki}-67$ expression in $\mathrm{CRC}$ lymph node metastasis does not predict survival. BioMed Res Int. 2015;2015:ID131685. https://doi.org/10.1155/2015/131685

26. Alameda F, Fuste P, Boluda S, Ferrer L, Baro T, Mariñoso L et al. The Ki-67 labeling index is not a useful predictor for the follow-up of cervical intraepithelial neoplasia. J Low Genit Tract Dis. 2004;8(4):313-6. https://doi.org/10.1097/00128360-200410000-00010

27. Stoll C, Baretton G, Ahrens C, Löhrs U. Prognostic significance of apoptosis and associated factors in oral squamous cell carcinoma. Virchows Arch. 2000;436(2):102-8. https://doi.org/10.1007/PL00008207

28. Silva SD, Morand GB, Alobaid FA, Hier MP, Mlynarek AM, Alaovi-Jamali MA et al. Epithelial-mesenchymal transition (EMT) markers have prognostic impact in multiple primary oral squamous cell carcinoma. Clin Exp Metastasis 2015;32(1):55-63. https://doi.org/10.1007/s10585-014-9690-1

29. Hua C, Zhao G, Li Y, Bie L. Minichromosome Maintenance (MCM) Family as potential diagnostic and prognostic tumor markers for human gliomas. BMC Cancer. 2014;14(1):526. https://doi.org/10.1186/1471-2407-14-526

30. Gueiros LA, Coletta RD, Kowalski LP, Lopes MA. Clinicopathological features and proliferation markers in tongue squamous cell carcinomas. Int J Oral Maxillofac Surg. 2011;40(5):510-5. https://doi.org/10.1016/j.ijom.2010.12.008

31. Igci $Y Z$, Erkilic S, Igci M, Arslan A. MCM3 Protein expression in follicular and classical variants of papillary thyroid carcinoma. Pathol Oncol Res. 2014;20(1):87-91. https://doi.org/10.1007/s12253-013-9662-9

32. Söling A, Sackewitz M, Volkmar M, Schaarschmidt D, Jacob R, Holzhausen $\mathrm{HJ}$ et al. Minichromosome maintenance protein 3 elicits a cancer-restricted immune response in patients with brain malignancies and is a strong independent predictor of survival in patients with anaplastic astrocytoma. Clin Cancer Res. $2005 ; 11(1): 249-58$.
33. Nodin B, Fridberg $M$, Jonsson L, Bergman J, Uhlén $M$, Jirström K. High MCM3 expression is an independent biomarker of poor prognosis and correlates with reduced RBM3 expression in a prospective cohort of malignant melanoma. Diagn Pathol. 2012;7(1):82. https://doi.org/10.1186/1746-1596-7-82

34. Lau KM, Chan QK, Pang JC, Li KK, Yeung WW, Chung NY et al. Minichromosome maintenance proteins 2, 3 and 7 in medulloblastoma: overexpression and involvement in regulation of cell migration and invasion. Oncogene. 2010;29(40):5475-89. https://doi.org/10.1038/onc.2010.287

35. Ahn JH, Chang HK. Expression of minichromosome maintenance protein 7 and Smad 4 in squamous cell carcinoma of the esophagus.

Korean J Pathol. 2010;44(4):346-53. https://doi.org/10.4132/KoreanJPathol.2010.44.4.346

36. Valverde LDF, Freitas RD, Pereira TDA, Resende MF, Ara IM, Santos JN et al. MCM3: a novel proliferation marker in oral squamous cell carcinoma. Appl Immunohistochem Mol Morphol. 2016. https://doi.org/10.1097/PAl.0000000000000397

37. Tamura T, Shomori K, Haruki T, Nosaka K, Hamamoto Y, Shiomi T et al. Minichromosome maintenance- 7 and geminin are reliable prognostic markers in patients with oral squamous cell carcinoma:immunohistochemical study. J Oral Pathol Med. 2010;39(4):328-34. Duplicata da 12

38. Szelachowska J, Dziegiel P, Jelen-Krzeszewska J, Jelen M, Matkowski R, Pomiecko A et al. Mcm-2 protein expression predicts prognosis better than $\mathrm{Ki}-67$ antigen in oral cavity squamocellular carcinoma. Anticancer Res. 2006;26(3B):2473-8.

39. Yu SY, Wang YP, Chang JY, Shen WR, Chen HM, Chiang. Increased expression of MCM5 is significantly associated with aggressive progression and poor prognosis of oral squamous cell carcinoma. J Oral Pathol Med. 2014;43(5):344-9. https://doi.org/10.1111/jop.12134

40. Feng CJ, Li HJ, Li JN, Lu YJ, Liao GQ. Expression of Mcm7 and $\mathrm{Cdc} 6$ in oral squamous cell carcinoma and precancerous lesions. Anticancer Res. 2008;28(6A):3763-9. 